American Medical Journal 3 (2): 203-209, 2012

ISSN 1949-0070

(C) 2012 Science Publications

\title{
Effects of Body Weight-Support Treadmill Training in Incomplete Spinal Cord Injury: A Critical Review
}

\author{
${ }^{1}$ Renata Teles Vieira, ${ }^{2}$ Rafaela Machado de Gusmao Oliveira, \\ ${ }^{2}$ Camila Alves Nogueira Barros, ${ }^{1}$ Leonardo Caixeta and ${ }^{3,4}$ Sergio Machado \\ ${ }^{1}$ Faculty of Medicine, Federal University of Goiás, Goiás-GO, Brazil \\ ${ }^{2}$ Center for Advanced Studies and Integrated Formation, Goiás-GO, Brazil \\ ${ }^{3}$ Quiropraxia Program, Central University, Santiago, Chile \\ ${ }^{4}$ Panic and Respiration Lab, Institute of Psychiatry, \\ Federal University of Rio de Janeiro (IPUB/UFRJ), Rio de Janeiro, Brazil
}

\begin{abstract}
Problem statement: The present study reviewed the efficacy of body-weight support treadmill training in patients with incomplete spinal cord injury. Approach: We developed a computer-supported search strategy for finding studies in the main data bases: Pubmed/Medline, ISI Web of Knowledge and Scielo. We also developed a manual search withing all electronically references found. The search terms gait, locomotor training, spinal cord injury, SCI, body-weight support treadmill training were used. Only papers published in English and conducted from 1991 up to 2012 were preferentially reviewed. The inclusion criteria were: (a) studies using body-weight support treadmill training in patients with iSCI; (b) studies with iSCI patients classified as ASIA C or D. The exclusion criteria were: (a) studies comparing the BWSTT with manual and robotic techniques and associated BWSTT with the use of drugs. Results: After a careful electronic search in the data bases, forty seven articles were found. Studies with patients of ASIA A and/or B ${ }^{26}$ classification, studies comparing the BWSTT with manual and robotic techniques and studies associating BWSTT with the use of drugs were excluded of the study. Thus, only 21 articles were selected. Conclusion: iSCI is a severe neurological condition that causes serious compromises, such as gait disability. The wide use of BWSTT seems to be an effective, safe and reliable method for functional rehabilitation of gait. Even though, there is no sufficient scientific evidence to confirm that the BWSTT is superior to the other rehabilitation techniques.
\end{abstract}

Key words: Spinal Cord Injury (SCI), range of motion, Body Weight Support Treadmill Training (BWSTT), rehabilitation techniques

\section{INTRODUCTION}

Approximately 259,000 people with a Spinal Cord Injury (SCI) live in the United States. SCI is classified according two criteria: the neurological level and if the injury is complete or incomplete. Of those SCI patients, approximately $30.1 \%$ have incomplete tetraplegia. This level of lesion is classified " $\mathrm{D}$ " on the American Spinal Injury Association Impairment Scale (AIS), due to the preservation of some sensorimotor functions below the level of injury, often at the level of cervical backbone (NSCISC, 2009).

The ability of muscle to function against gravity is preserved in more than half of all muscle groups below the neurological level of injury. However gait patterns in this population often reflect incoordination of muscle action, leading to inefficient gait, with high-level energy consumption (Cunha-Filho et al., 2003). Although able to ambulate, these people are often unable to isolate specific muscle patterns to ambulate at functional speeds and without significant gait deviations. Gait impairments in people with incomplete SCI (iSCI) are not only induced by alterations in motor control, but also by muscle weakness, decreased range of motion and decreased muscle extensibility (Gracies, 2005; Biering-Sorensen et al., 2009), improving quality of life through functional independence, improving self esteem and social inclusion of these patients.

In addition to its severity and irreversibility, the iSCI requires long and costly rehabilitation programs that in general lead to functional recovery. In front of the difficulties of the traditional gait training, Body Weight Support Treadmill Training (BWSTT) was created (Cunha et al., 2002). It allows for the repetitive 
practice of walking/stepping in a controlled environment, which the patient's weight is partially unloaded and sensory input is provided that facilitates normal walking parameters (Cunha et al., 2002; Visitin et al., 1998; Wilson et al., 2001; Field-Fote, 2000) Research has shown improvements in functional walking ability in both acute and chronic ISCI populations after locomotor training with BWSTT (Hicks et al., 2005; Wernig et al., 1998; Wirz et al., 2005).

The theoretical basis for the emergence of BWSTT results from studies in cats with spinal cord injuries that have passed through gait training (Threlkeld et al., 2003). From these studies it was found a central pattern generator that was responsible for generating the cyclical pattern of movement in the central nervous system of these animals, even with little training after SCI (Duysens and Crommert, 1998; Schindl et al., 2000; Miyai et al., 2000). Historically, BWSTT is linked to neurological impairment, which was firstly used in stroke patients (Hesse et al., 1999; Barbeau and Visintin, 2003) and SCI (Visintin and Barbeau, 1989; Gardner et al., 1998), but now it has been used to treat various neurological and orthopedic diseases. Thus, this study aims to investigate the efficacy of BWSTT in iSCI rehabilitation.

\section{MATERIALS AND METHODS}

The present paper reviewed the efficacy of bodyweight support treadmill training in patients with iSCI. We developed a computer-supported search strategy for finding studies in the main data bases: Pubmed/Medline, ISI Web of Knowledge and Scielo. We also developed a manual search withing all electronically references found. The search terms gait, locomotor training, spinal cord injury, SCI, bodyweight support treadmill training were used. Only papers published in English and conducted from 1991 up to 2009 were preferentially reviewed. The inclusion criteria were: (a) studies using BWSTT in patients with iSCI; (b) studies with iSCI patients classified as ASIA $\mathrm{C}$ or D; (c) studies using BWSTT in combination with electrical stimulation in patients with iSCI. The exclusion criteria were: (a) studies comparing the BWSTT with manual and robotic techniques and associating BWSTT with the use of drugs.

\section{RESULTS}

After a careful electronic search in the data bases, forty seven articles were found. Studies with patients of ASIA A and/or B (Maynard et al., 1997) classification, studies comparing the BWSTT with manual and robotic techniques and studies associating BWSTT with the use of drugs were excluded of the study. Thus, 14 studies were selected and the main were summarized in Table 1 with their respective methods and outcomes.

\section{DISCUSSION}

Fourteen of the twenty-one articles found (Gardner et al., 1998; Field-Fote and Tepavac, 2002; Wernig and Müller, 1992; Wernig et al., 1995; 1998; Nymark et al., 1998; Behrman and Harkema, 2000; Protas et al., 2001; Field-Fote, 2001; Postans et al., 2004; Field-Fote et al., 2005; Lucareli et al., 2008; Behrman et al., 2008) showed that treatment with BWSTT in iSCI (ASIA C and D) have positive effects on spatial and temporal parameters of gait, such as symmetry, $\mathrm{O} 2$ consumption (lower energy expenditure), coordination, swinging arms, motor function, stride length, distance and walking speed. The remaining of studies showed other effects of BWSTT beyond gait characteristics. Improved blood glucose regulation (Phillips et al., 2004), little or any improvement in quality of life (Lucareli et al., 2008; Effing et al., 2006), changes in electromyographic activity in the main muscles of gait (Gorassini et al., 2009) and increase in muscle fiber were also observed after BWSTT.

Three out 21 studies (Wernig et al., 1995; 1998; Field-Fote et al., 2005) were randomized clinical trials and/or experimental studies of more than 20 patients. The rest were case reports, case-control pilot study and /or experimental studies of less than 20 patients. Despite the positive outcomes found in favor of BWSTT, reliable scientific evidence is needed in order to confirm these findings.

BWSTT provides specific activation of the neuromuscular system below the level of injury in order to "retraining" the CNS and restore motor skills. Researchers examined the role of the spinal cord to control the walk and found that cats with complete transection of thoracic spinal cord could restore locomotion, after intense practice of walking exercises, in order to improving normal gait parameters, such as, walking speed and appropriate kinematic (Behrman and Harkema, 2007).

Within this context, BWSTT is tough to be superior compared to conventional gait training in neurological disorders, such as stroke (Cunha et al., 2002; Daly et al., 2004; Visintin and Barbeau, 1998), Cerebral Palsy (CP) (Schindl et al., 2000) and Parkinson's Disease (PD) (Miyai et al., 2000). In stroke patients, a randomized clinical trial was conducted comparing the conventional physical therapy intervention (4 daily sessions, $3 \mathrm{~h}$ each) with BWSTT (4 daily sessions, 20 min. each) in 15 stroke patients in acute phase $(<6$ weeks). Investigators verified the functional gait, the speed obtained in 5 meters, the distance traveled in 5 min and the energy expenditure (oxygen consumption $-\mathrm{VO}^{2} \max$.). 
Am. Med. J. 3 (2): 203-209, 2012

Table 1: Summary of BWSTT studies in SCI rehabilitation

\begin{tabular}{|c|c|c|c|}
\hline Authors & $\mathrm{N}$ & Protocol & Outcomes \\
\hline Wernig and Müller (1992) & $\begin{array}{l}8 \text { iSCI (male) } \\
\text { (5-20 years after injury) }\end{array}$ & $\begin{array}{l}\text { The time of treatment was } 1 \frac{1 / 2}{2} \text { to } \\
7 \text { months, therapy session ranged } \\
\text { from } 30-60 \text { min. The use of } \\
\text { BWSTT started with } 40 \% \text {. }\end{array}$ & $\begin{array}{l}\text { The distance increased after training. } \\
\text { The important phenomenon observed } \\
\text { was that patients with absent } \\
\text { voluntary activity in the limb at rest, } \\
\text { was able to ambulate } 100-200 \\
\text { meters (locomotor automatism). }\end{array}$ \\
\hline Wernig et al. (1995) & $\begin{array}{l}89 \text { iSCI (male) } \\
44 \text { in chronic phase and } 45 \\
\text { (in acute phase) } 64 \text { controls }\end{array}$ & $\begin{array}{l}\text { The treatment with BWSTT had } \\
\text { an average of } 10.5 \text { weeks ( } 3-20 \text { weeks), } \\
\text { and patients who ambulate, improved } \\
\text { therapy session } 30 \text { min. ( } 5 \text { times/week). }\end{array}$ & $\begin{array}{l}\text { Patients acquired independent gait, } \\
\text { speed and performance of the gait. } \\
\text { Although there has been little } \\
\text { improvement in voluntary } \\
\text { muscle activity. }\end{array}$ \\
\hline Gardner et al. (1998) & 1 iSCI (male) & $\begin{array}{l}\text { Patient injured between C5-C6. } \\
\text { Training in the BWSTT with } 40 \% \\
\text { weight bearing, for } 6 \text { weeks } \\
\text { ( } 3 \text { times/week) } 16 \text { sessions } \\
\text { ( } 20 \text { min each). }\end{array}$ & $\begin{array}{l}\text { Improved performance in } \\
\text { the race and in the } \\
\text { cadence of the gait. }\end{array}$ \\
\hline Wernig et al. (1998) & $\begin{array}{l}76 \text { iSCI (male) } \\
(35 \text { in chronic phase and } \\
41 \text { in acute phase) }\end{array}$ & $\begin{array}{l}\text { Patients trained in the BWSTT an } \\
\text { average of } 12 \text { weeks (sessions } \\
\text { with } 30 \text { min.( } 5 \text { times/week) } \\
\text { and patients in acute phase, } \\
\text { trained in BWSTT, an average of } \\
10 \text { weeks (sessions with } 30 \\
\text { min, } 5 \text { times/week). }\end{array}$ & $\begin{array}{l}\text { Improved function of moving from } \\
\text { wheelchair to walking. } \\
\text { Ambulation patients, improved gait } \\
\text { speed and endurance and keep } \\
\text { the winnings for an } \\
\text { extended period after training. }\end{array}$ \\
\hline Nymark et al. (1998) & $\begin{array}{l}5 \text { iSCI (male) } \\
\text { (sub acute phase, } 2 \\
\text { months after injury) }\end{array}$ & $\begin{array}{l}\text { Patients injury among C2-T10. } \\
\text { All participants trained in the } \\
\text { BWSTT for } 36 \text { sessions } \\
\text { (1 h each) along } 3 \text { months. }\end{array}$ & $\begin{array}{l}\text { Improved range of motion } \\
\text { and kinematic measures } \\
\text { temporal and spatial) of the gait. } \\
\text { (More weight bearing in lower limbs. }\end{array}$ \\
\hline $\begin{array}{l}\text { Behrman and Harkema } \\
\text { (2000) }\end{array}$ & 3 iSCI (male) & $\begin{array}{l}\text { Patients ASIA C and D training } \\
\text { in the BWSTT. } \\
\text { Case } 1 \text { - Men, } 20 \text { years, } \\
\text { injury in T5, ASIA C, one } \\
\text { month after the event, with key } \\
\text { muscles motor score } 2 / 50 \text { in lower limbs. } \\
\text { Case } 2 \text { - Men } 43 \text { years, injury } \\
\text { in C6, } 8 \text { months after trauma, } \\
\text { ASIA D, key muscles score } 32 / 50 \text {. } \\
\text { Case } 3 \text { - Men, } 45 \text { years, injury in } \\
\text { T-9, ASIA D, lower limbs } \\
\text { key muscles score } 46 / 50 \text {. }\end{array}$ & $\begin{array}{l}\text { Case 1- Improved walking speed } \\
\text { and independence at home, } \\
\text { just starting to use a cane for mobility. } \\
\text { After the whole training, } \\
\text { progressed to Asia D and Key } \\
\text { muscles improved to } 38 / 50 \text {. } \\
\text { Case 2- After training, } \\
\text { remained ASIA D, key muscles } \\
\text { score improved to 34/50. } \\
\text { After complete training became } \\
\text { full time ambulant with crutches. } \\
\text { Improvement in walking speed, } \\
\text { balance, fall risk and quality of life. } \\
\text { Case } 3 \text { - He did not have any change } \\
\text { in classification and motor } \\
\text { score of ASIA, improved in } \\
\text { climbing stairs and walking speed. }\end{array}$ \\
\hline Protas et al. (2001) & 3 iSCI (male) & $\begin{array}{l}\text { Patients iSCI injured in thoracic } \\
\text { level, } 2 \text { cases ASIA D and } 1 \text { case } \\
\text { ASIA C. Training in the BWSTT with } \\
40 \% \text { weight bearing, sessions } \\
\text { of } 20 \text { min, } 5 \text { times/ } \\
\text { week during } 3 \text { months. }\end{array}$ & $\begin{array}{l}\text { All three patients improved } \\
\text { in walking speed and efficiency, } \\
\text { reduced } \mathrm{O}_{2} \text { consumption in } 68 \% \text {. } \\
\text { The muscle function did not change. }\end{array}$ \\
\hline Field-Fote (2001) & 19 iSCI (male) & $\begin{array}{l}\text { ( }<1 \text { year after injury) Assess } \\
\text { the use of BWSTT associated } \\
\text { with electrical stimulation in peroneal } \\
\text { nerve. The treatment lasted } 3 \\
\text { months ( } 3 \text { times/week) } \\
\text { with sessions of } 1.5 \mathrm{~h} \text {. }\end{array}$ & $\begin{array}{l}\text { Individual with some ability to } \\
\text { ambulate received benefits from } \\
\text { BWSTT associated with electrical } \\
\text { stimulation, improved gait speed. }\end{array}$ \\
\hline Field-Fote and & 14 iSCI (male) & Patients SCI ASIA C, injury below & Patients walked at a speed \\
\hline Tepavac (2002) & 3 controls (male) & $\begin{array}{l}\text { T-10, average of } 70 \text { months } \\
\text { after injury. } 12 \text { weeks of } \\
\text { treatment }(3 \text { times/week) } \\
\text { total of } 36 \text { sessions. }\end{array}$ & $\begin{array}{l}84 \% \text { higher than the initial } \\
\text { and improved coordination. }\end{array}$ \\
\hline Postans et al. (2004) & $\begin{array}{l}12 \text { iSCI (male) } \\
\text { (acute phase) }\end{array}$ & $\begin{array}{l}\text { Patients ASIA C e D. } \\
\text { The treatment lasted } 4 \text { weeks }\end{array}$ & $\begin{array}{l}\text { The group that received BWSTT } \\
\text { obtained better results on }\end{array}$ \\
\hline
\end{tabular}


Am. Med. J. 3 (2): 203-209, 2012

Table 1: Continue

\begin{tabular}{|c|c|c|c|}
\hline Stewart et al. (2004) & 9 iSCI (male) & $\begin{array}{l}\text { using BWSTT associated with } \\
\text { electrical stimulation ( } 5 \text { sessions/week) } \\
\text { for } 25 \text { min, just as occurred } \\
\text { in the control period performed } \\
\text { with conventional physiotherapy. } \\
\text { Patients ASIA C, accomplished }\end{array}$ & $\begin{array}{l}\text { performance and walking speed } \\
\text { compared to control. } \\
\text { In addition, spasticity and } \\
\text { muscle strength have not showed } \\
\text { differences after both treatments. }\end{array}$ \\
\hline stewart el at. (2004) & YISTL (male) & $\begin{array}{l}68 \text { sessions of BWSTT ( } 3 \text { times/week). } \\
\text { Time of session was not reported. } \\
\text { Started with } 65 \pm 3 \% \text { of } \\
\text { body weight support. }\end{array}$ & $\begin{array}{l}\text { Increased muscle fiber area of } \\
\text { type I and IIa. Improved lipid } \\
\text { profile (decreased LDL). } \\
\text { No change in body fat. }\end{array}$ \\
\hline Phillips et al. (2004) & 9 iSCI (male) & $\begin{array}{l}\text { Patients ASIA C and developed } \\
\text { the treatment using BWSTT for } \\
6 \text { months ( } 3 \text { times/week) } \\
68 \text { total sessions. } \\
\text { Started with } 65 \pm 3 \% \\
\text { of body weight support. }\end{array}$ & $\begin{array}{l}\text { Improved blood glucose regulation } \\
\text { (increased glucose intolerance) } \\
\text { and increased insulin sensitivity. }\end{array}$ \\
\hline Behrman et al. (2005) & 1 iSCI (male) & $\begin{array}{l}\text { Patient, injury in C6-7, ASIA D, } \\
\text { ambulation for three years with a rolling } \\
\text { walker and right AFO brace. } \\
45 \text { sessions of locomotor training } \\
\text { were performned, } 5 \\
\text { sessions per week, } 30 \text { min. } \\
\text { BWSTT training, } 20 \text { min. } \\
\text { Walk on the ground and } \\
\text { community ambulation. }\end{array}$ & $\begin{array}{l}\text { Evolved from home ambulant } \\
\text { with orthesis to community ambulation } \\
\text { using crutches, improve gait speed, } \\
\text { becoming more symmetrical, with the } \\
\text { balance of the upper limbs, } \\
\text { coordination and appropriate steps. } \\
\text { The number of steps measured } \\
\text { for } 24 \mathrm{~h} \text { also increased. }\end{array}$ \\
\hline Field-Fote et al. (2005) & $\begin{array}{l}27 \text { iSCI (male) } \\
\text { (<1 year after injury) }\end{array}$ & $\begin{array}{l}\text { Patients with injury above T-10, } \\
\text { received treatment with BWSTT } \\
\text { during } 12 \text { weeks ( } 5 \text { times/ } \\
\text { week), } 60 \mathrm{~min} / \text { session. }\end{array}$ & $\begin{array}{l}\text { An improvement in walking speed, } \\
\text { stride length and } \\
\text { symmetry was observed. }\end{array}$ \\
\hline Effing et al. (2006) & $\begin{array}{l}3 \text { iSCI (male) } \\
\text { (>4 years injury) }\end{array}$ & $\begin{array}{l}\text { Patients, } 2 \text { ASIA C } \\
\text { and } 1 \text { ASIA D performed BWSTT } \\
\text { for } 12 \text { weeks ( } 5 \text { times/ } \\
\text { week) } 30 \text { min each session. }\end{array}$ & $\begin{array}{l}\text { A discreet improvement was } \\
\text { observed in quality of life. }\end{array}$ \\
\hline Lucareli et al. (2008) & $\begin{array}{l}12 \text { iSCI (male) } \\
\text { ( }<1 \text { year after injury) } \\
12 \text { controls (male) }\end{array}$ & $\begin{array}{l}12 \text { patients iSCI, ASIA C and D } \\
\text { accomplished } 30 \text { sessions } \\
(2 \text { times/week) during } 4 \text { months } \\
\text { with BWSTT and } 12 \text { patients } \\
\text { received physical therapy in } \\
\text { the control group with } \\
\text { the same procedure. }\end{array}$ & $\begin{array}{l}\text { Increased speed distance, cadence, } \\
\text { stride length, total cycle time } \\
\text { and decreased support time on the gait. } \\
\text { The BWST was more effective } \\
\text { than conventional physiotherapy } \\
\text { on gait kinematic parameters. }\end{array}$ \\
\hline Lucareli et al. (2008) & $\begin{array}{l}12 \text { iSCI (male) } \\
\text { (>1 year after injury) }\end{array}$ & $\begin{array}{l}\text { Assessed the use of BWSTT } \\
\text { in patients ASIA C e D, ambulant. } \\
\text { Treatment lasted } 4 \text { months } \\
30 \text { sessions, } 30 \text { min each), } \\
\text { ( } 2 \text { times/week. }\end{array}$ & $\begin{array}{l}\text { There was improvement in } \\
\text { the temporo-spatial parameters } \\
\text { of gait, three showed no } \\
\text { improvement in quality of life. }\end{array}$ \\
\hline Behrman et al. (2008) & $\begin{array}{l}1 \text { iSCI (4 1/2 years) } \\
\text { (male) }\end{array}$ & $\begin{array}{l}\text { Training in BWSTT, ASIA C, } \\
\text { injury in C- } 7,3 \text { months after } \\
\text { injury, wheelchair dependent, } \\
\text { LEMS } 4 / 50.16 \text { months of treatment, } \\
76 \text { total sessions, } 20-30 \text { min of BWST. }\end{array}$ & $\begin{array}{l}\text { Showed after the first month of } \\
\text { treatment: voluntary steps, } \\
\text { progressing with the ability to walk } \\
\text { with a rolling walker. At the end of } \\
\text { locomotor training, walking } \\
\text { independently, with significant } \\
\text { There was no change in LEMS score. }\end{array}$ \\
\hline Musselman et al. (2009) & 4 iSCI (male) & $\begin{array}{l}\text { Assessed } 4 \text { SCI patients ASIA C. All } \\
\text { patients started BWSTT treatment. } \\
\text { After, } 2 \text { of them receive skills training } \\
\text { (walking on different surfaces, gait } \\
\text { training with obstacles, walking long } \\
\text { distances and others) and the rest } \\
\text { continued with BWSTT. In the third } \\
\text { phase of treatment, reversed the order } \\
\text { of treatment. Each treatment phase lasted } \\
3 \text { months, } 1 \text { h each session ( } 5 \text { times/week). }\end{array}$ & $\begin{array}{l}\text { There was no improvement in } \\
\text { static and/or dynamic balance. } \\
\text { The walking speed improved } \\
\text { during treatment with motor } \\
\text { skills, higher than BWSTT. }\end{array}$ \\
\hline
\end{tabular}

Legend: AIS = American Spinal Injury Association impairment scale BWSTT = body weight treadmill training; LDL = Low Density Lipoprotein; Lower Extremity Motor Score (LEMS); iSCI = incomplete Spinal Cord Injury 
The sample size probably did not allow a statistically significant difference, however the investigators were able to observe large differences in distance traveled and energy expenditure of the group that received BWSTT compared to conventional physical therapy group (Cunha et al., 2002). In another study, 43 poststroke patients received BWST treatment and 36 patients were treated with conventional gait training. Both groups were treated for 6 weeks $(2$ sessions per week, $20 \mathrm{~min}$ each). Investigators verified the balance, motor recovery, walking speed and strength. There were statistical differences for all parameters, with better results for BWSTT group. They conclude that increasing gradually the body weight is more advantageous and contributes to better balance and gait capacity when compared to conventional training on the treadmill (Visintin and Barbeau, 1998). Daly et al. (2004), studied 16 post-stroke patients over 12 weeks, 4 times a week, $90 \mathrm{~min}$ each session. They compared a group of 9 patients who were treated with BWSTT in combination to Functional Neuromuscular Stimulation (FNS) with Intramuscular (IM) electrodes (FNS-IM) to a group of 7 patients who received only BWSTT. Outcome measures were kinematics of gait swing phase. There were no statistical significant differences between groups, with no significant pre-/post-treatment gains in peak swing hip flexion. BWSTT had no significant gains in other gait components at posttreatment or at follow-up. BWSTT+FNS-IM group had significant gains in peak swing knee flexion and midswing ankle dorsiflexion that were maintained for 6 months.

In addition, in patients with CP, BWSTT also aided in gait and motor skills, posture, balance and improved scores on the Gross Motor Function Measure (GMFM) scale, in 6 out 10 patients that cannot walk, demonstrating the effectiveness of BWSTT also in patients depending on the gait (Schindl et al., 2000).

In PD patients, BWSTT was superior compared to conventional physical therapy treatment. Ten PD patients were investigated and statistical difference was observed between conventional physical therapy and BWSTT groups. An improvement in motor performance and mobility of gait were found, leading to an enhancement of activities of daily life (Miyai et al., 2000).

With respect to iSCI, several studies showed significant clinical effects (Field-Fote et al., 2005; Gardner et al., 1998; Field-Fote and Tepavac, 2002; Wernig and Wernig, 1992; Wernig et al., 1995; 1998; Nymark et al., 1998; Behrman and Harkema, 2000; Protas et al., 2001; Field-Fote, 2001; Postans et al., 2004; Field-Fote et al., 2005; Lucareli et al., 2008; Behrman et al., 2008; Musselman et al., 2009; Phillips et al., 2004; Behrman et al., 2005). For instance, the study of Field-Fote et al. (2005) assessed gait of 27 iSCI patients $(<1$ year after injury, above T-10). After 12 weeks (5 sessions/week) treatment with BWSTT there was improvement in gait speed and step length and symmetry (Field-Fote et al., 2005). Another study examined 12 iSCI patients (ASIA C and D) in acute phase. Each patient was his own control in second period. In the first period, they received conventional physical therapy and BWSTT, beginning with a withdrawal of $40 \%$ of body weight associated with FNS. The treatment lasted four weeks (5 sessions/week) with $25 \mathrm{~min}$ per session for both treatment periods. The findings of first period were superior compared to second period on performance and walking speed. However, spasticity and muscle strength were not significant different between periods of treatment (Postans et al., 2004). Stewart et al. (2004) showed that after 6 months of treatment (3 sessions/week), iSCI patients (ASIA C) showed improvement in lipid profile with decreased LDL, increased muscle fiber area of type I and IIa, but no changes in body fat mass. Similar results were found by Phillips et al. (2004). They examined iSCI patients (ASIA C) and treated them with BWSTT for 6 months (3 times/week) with a total of 68 sessions, observing improvement in regulation of blood glucose (glucose tolerance) and increased insulin sensitivity.

\section{CONCLUSION}

iSCI is a severe neurological condition that causes serious compromises, such as gait disability. Most of studies of BWSTT showed better physiological and psychological effects than studies using conventional gait training. BWSTT appears to be more effective when combined with electrical stimulation. In contrast, no benefits were found for BWSTT in the improvement of muscular strength and bone density, spasticity and body fat. Moreover, BWSTT showed reduction in energy expenditure measured by oxygen consumption $\left(\mathrm{VO}^{2} \max \right)$ and decrease in heart rate after training. These findings indicate decrease in chances of a traumatic event such as cardiac arrest or shortness of breath during training and decrease in fatigue during and after training. However, BWSTT does not seem to prevent loss of bone density in both acute and chronic phases of iSCI. Even though, BWSTT seems to be effective, safe and reliable method for functional rehabilitation of gait, there is still no sufficient scientific evidence to confirm it. Therefore, more controlled studies are required to better understand the efficacy of BWSTT in iSCI. 


\section{REFERENCES}

Barbeau, H. and M. Visintin, 2003. Optimal outcomes obtained with body-weight support combined with treadmill training in stroke subjects. Arch. Phys. Med. Rehabil., 84: 1458-1465. PMID: 14586912

Behrman, A.L. and S.J. Harkema, 2000. Locomotor training after human spinal cord injury: A series of case studies. Phys. Ther., 80: 688-700. PMID: 10869131

Behrman, A.L. and S.J. Harkema, 2007. Physical rehabilitation as an agent for recovery after spinal cord injury. Phys. Med. Rehabil. Clin. N. Am., 18: 183-202. PMID: 17543768

Behrman, A.L., A.R. Lawless-Dixon, S.B. Daviis, M.G. Bowdwn and C.P. Nair et al., 2005. Locomotor Training progression and outcomes after incomplete spinal cord injury. Phys. Ther., 85: 1356-13571. PMID: 16305274

Behrman, A.L., P.M. Nair, M.G. Bowden, R.C. Dauser and B.R. Herget et al., 2008. Locomotor training restores walking in a nonambulatory child whith chronic, severe, incomplete cervical spinal cord injury. Phys. Ther., 88: 580-590. PMID: 18326054

Biering-Sorensen, B., I.B. Kristensen, M. Kjaer and F. Biering-Sørensen, 2009. Muscle after spinal cord injury. Muscle Nerve, 40: 499-519. PMID: 19705475

Cunha, I.T.D. Jr., P.A. Lim, H. Qureshy, H. Henson and T. Monga et al., 2002. Gait outcomes after acute stroke rehabilitation with supported treadmill ambulation training: A randomized controlled pilot study. Arch Phys. Med. Rehab., 83: 1258-1265. PMID: 12235606

Cunha-Filho, I.T.D., H. Henson, H. Qureshy, A.L. Williams and S.A. Holmes et al., 2003. Differential responses to measures of gait performance among healthy and neurologically impaired individuals. Arch. Phys. Med. Rehabil., 84: 1774-1779. PMID: 14669182

Daly, J.J., K.L. Roengk, K.M. Butler, J.L. Gansen and E. Fredrickson et al., 2004. Response of sagittal plane gait kinematics to weight-supported treadmill training and functional neuromuscular stimulation following stroke. J. Rehabil. Res. Dev., 41: 807820. PMID: 15685469

Duysens, J. and H.W.V.D. Crommert, 1998. Neural control of locomotion; The central pattern generator from cats to humans. Gait Posture, 7: 131-41. PMID: 10200383
Effing, T.W., N.L.V. Meeteren, F.W.V. Asbeck and A.J. Prevo, 2006. Body weight-supported treadmill training in chronic incomplete spinal cord injury: A pilot study evaluating functional health status and quality of life. Spinal Cord, 44: 287-296. PMID: 16186857

Field-Fote, E.C. and D. Tepavac, 2002. Improved intralimb coordination in people with incomplete spinal cord injury following training with body weight support and electrical stimulation. Phys. Ther., 82: 707-715. PMID: 12088467

Field-Fote, E.C., 2000. Spinal cord control of movement: Implications for locomotor rehabilitation following spinal cord injury. Phys. Ther., 80: 477-484. PMID: 10792858

Field-Fote, E.C., 2001. Combined use of body weight support, functional electric stimulation and treadmill training to improve walking ability in individuals with chronic incomplete spinal cord injury. Arch. Phys. Med. Rehabil., 82: 818-824. PMID: 11387589

Field-Fote, E.C., S.D. Lindley and A.L. Sherman, 2005. Locomotor training approaches for individuals with spinal cord injury: A preliminary report of walking-related outcomes. J. Neurol. Phys. Ther., 29: 127-138. PMID: 16398945

Gardner, M.B., M.K. Holden, J.M. Keikauskas and R.L. Ricahrd, 1998. Partial body weight support with treadmill locomotion to improve gait after incomplete spinal cord injury: A single-subject experimental design. Phys. Ther., 78: 361-375. PMID: 9555919

Gorassini, M.A., J.A. Norton, J. Nevett-Duchcherer, F.D. Roy and J.F. Yang, 2009. Changes in locomotor muscle activity after treadmill training in subjects with incomplete spinal cord injury. J. Neurophysiol., 101: 969-979. PMID: 19073799

Gracies, J.M., 2005. Pathophysiology of spastic paresis. I: Paresis and soft tissue changes. Muscle Nerve, 31: 535-551. PMID: 15714510

Hesse, S., M. Konrad and D. Uhlenrock, 1999. Treadmill walking with partial body weight support versus floor walking in hemiparetic subjects. Arch. Phys. Med. Rehabil., 80: 421-427. PMID: 10206604

Hicks, A.L., M.M. Adams, K. Martin Ginis, L. Giangregorio and A. Latimer et al., 2005. Longterm body-weight-supported treadmill training and subsequent follow-up in persons with chronic SCI: Effects on functional walking ability and measures of subjective well-being. Spinal Cord, 43: 291-298. PMID: 15685260 
Lucareli, P.R., M.O. Lima, F.P. Lima, S.A. Garbelotti and R.O. Gimenes et al., 2008. Gait analysis and quality of life evaluation after gait training in patients with spinal cord injury. Rev. Neurol., 46: 406-410. PMID: 18389459

Maynard, F.M. Jr., M.B. Bracken, G. Creasey, J.F. Ditunno and W.H. Donovan et al., 1997. international standards for neurological and functional classification of spinal cord injury. American Spinal Injury Association. Spinal Cord, 35: 266-274. PMID: 9160449

Miyai, I., Y. Fujimoto, Y. Veda, Y. Ueda and H. Yamamoto et al., 2000. Treadmill training with body weight support: Its effect on Parkinson's disease. Arch. Phys. Med. Rehabil., 81: 849-852. PMID: 10895994

Musselman, K.E., K. Fouad, J.E. Misiaszek and J.F. Yang, 2009. Training of walking skills overground and on the treadmill: Case series on individuals with incomplete spinal cord injury. Phys. Ther., 89: 601-611. PMID: 19423643

NSCISC, 2009. Spinal cord injury facts and figures at a glance. NSCISC.

Nymark, J., D. DeForge, H. Barbeau, M. Badour and S. Bercovitch et al., 1998. Body weight support treadmill gait training in the subacute recovery phase of incomplete spinal cord injury. Neurorehabil. Neural Repair., 12: 119-136. DOI: $10.1177 / 154596839801200307$

Phillips, S.M., B.G. Stewart, D.J. Mahoney, A.L. Hicks and N. McCartney et al., 2004. Body-weightsupport treadmill training improves blood glucose regulation in persons with incomplete spinal cord injury. J. Applied Physiol., 97: 716-724. PMID: 15107410

Postans, N.J., J.P. Hasler, M.H. Granat and D.J. Maxwell, 2004. Functional electric stimulation to augment partial weight-bearing supported treadmill training for patients with acute incomplete spinal cord injury: A pilot study. Arch. Phys. Med. Rehabil., 85: 604-610. PMID: 15083437

Protas, E.J., S.A. Holmes, H. Qureshy, A. Johnson and D. Lee et al., 2001. Supported treadmill ambulation training after spinal cord injury: A pilot study. Arch. Phys. Med. Rehabil., 82: 825-831. PMID: 11387590
Schindl, M.R., C. Forstner, H. Kern and S. Hesse, 2000. Treadmill training with partial body weight support in nonambulatory patients with cerebral palsy. Arch. Phys. Med. Rehabil., 81: 301-306. PMID: 10724074

Stewart, B.G., M.A. Tarnopolsky, A.L. Hicks, N. McCartney and D.J. Mahoney et al., 2004. Treadmill training-induced adaptations in muscle phenotype in persons with incomplete spinal cord injury. Muscle Nerve, 30: 61-68. PMID: 15221880

Threlkeld, A.J., L.D. Cooper, B.P. Monger, A.N. Craven and H.G. Haupt, 2003. Temporospatial and kinematic gait alterations during treadmill walking with body weight suspension. Gait Posture, 17: 235-245. PMID: 12770637

Visintin, M. and H. Barbeau, 1989. The effects of body weight support on the locomotor pattern of spastic paretic patients. Can. J. Neurol. Sci., 16: 315-325.

Visitin, M., H. Barbeau, N. Korner-Bitenski and N. Mayo, 1998. A new approach to retrain gait in stroke patients through body weight support and treadmill stimulation. Stroke, 29: 1122-1128. PMID: 9626282

Wernig, A. and S. Müller, 1992. Laufband locomotion with body weight support improved walking in persons with severe spinal cord injuries. Paraplegia, 30: 229-238. PMID: 1625890

Wernig, A., A. Nanassy and S. Muller, 1998. Maintenance of locomotor abilities following Laufband (treadmill) therapy in para- and tetraplegic persons: Follow-up studies. Spinal Cord, 36: 744-749. PMID: 9848480

Wernig, A., S. Müller, A. Nanassy and E. Cagol, 1995. Laufband therapy based on 'rules of spinal locomotion' is effective in spinal cord injured persons. Eur. J. Neurosci., 7: 823-829. PMID: 7620630

Wilson, M.S., H. Qureshy, E. Protas, A. Holmes and T.A. Krouskop et al., 2001. Equipment specifications for supported treadmill ambulation training. J. Rehabil. Res. Dev., 37: 415-422. PMID: 11028697

Wirz, M., D.H. Zemon, R. Rupp, A. Scheel, and G. Colombo et al., 2005. Effectiveness of automated locomotor training in patients with chronic incomplete spinal cord injury: A multicenter trial. Arch. Phys. Med. Rehabil., 86: 672-680. PMID: 15827916 